\title{
EKSPLORASI UNSUR MATEMATIKA DALAM KEBUDAYAAN MASYARAKAT JAWA
}

\author{
DEDY YUSUF ADITYA \\ yusufadit42@yahoo.co.id \\ Program Studi Teknik Informatika, Fakultas Teknik, Matematika, dan IPA \\ Universitas Indraprasta PGRI \\ Jl. Nangka 58. Tanjung Barat (TB Simatupang) Jagakarsa, Jakarta Selatan
}

\begin{abstract}
Abstrak. Penelitian ini bertujuan untuk mengetahui kandungan unsur-unsur Matematika dalam kebudayaan masyarakat Jawa khususnya Jawa Tengah. Metode penelitian yang digunakan adalah metode survey eksploratif dengan pendekatan kualitatif. Pengumpulan data dilakukan dengan triangulasi yaitu wawancara, observasi dan study pustaka. Kesimpulan yang diperoleh adalah bahwa terdapat dua unsur matematika dalam penentuan hari baik upacara adat mantu seperti unsur fakta mtematika dan unsur waktu.
\end{abstract}

Kata Kunci: Unsur Matematika, Kebudayaan

\begin{abstract}
This study aims to determine the content of elements of mathematics in the culture of Java society, especially Central Java. The research method used is explorative survey method with qualitative approach. Data collection was done by triangulation ie interview, observation and literature study. The conclusion obtained is that there are two elements of mathematics in the determination of good days of traditional ceremony "mantu" or wedding such as elements of fact mtematika and element of time.
\end{abstract}

Keywords: Mathematical Element, Culture

\section{PENDAHULUAN}

Etnomatematika adalah penggunaaan nilai-nilai matematika dalam suatu kebudayaan atau adat istiadat yang ada pada suatu komunitas masyarakat. Etnomatematika sering dan banyak sekali digunakan dalam masyarakat khusus-nya di Indonesia, hampir seluruh kehidupan masyarakat di Indonesia menggunakan etnomatematika dalam menjalani kehidupan bermasyarakat. Etnomatematika digunakan masyarakat indonesia antara lain dalam menentukan hari-hari besar upacara adat dan masih banyak lagi penggunakaan etnomatematika dalam kehidupan masyarakat.

Suku Jawa merupakan suku yang sangat besar yang ada di Indonesia. Masyarakat yang menyatakan diri sebagai suku Jawa adalah seluruh masyarakat Jawa Tengah, DI Yogyakarta, Jawa Timur dan sebagian Jawa Barat. Masyarakat suku Jawa juga banyak tersebar hampir di seluruh wilayah Indonesia. Seiring dengan perkembangan jaman yang semakin modern membuat masyarakat suku Jawa mulai meninggalkan kebudayaan suku Jawa (Kejawen). Namun bagi masyarakat yang masih menetap di daerah asalnya masih sangat memegang adat dan kebudayaan mereka.

Bagi masyarakat Jawa (Sragen) ajaran kejawen adalah ajaran yang bersifat mutlak. Anjuran dan larangannya harus selalu dipatuhi mereka percaya bahwa untuk melakukan berbagai kegiatan haruslah berpatokan pada ajaran kejawen, jika melanggar maka mereka percaya akan timbul berbagai kesialan dan malapetaka. Peran etnomatematika bagi masyakat Jawa (Sragen) adalah memberikan peluang atau probabilitas dalam memilih suatu keputusan khususnya dalam menentukan hari baik dalam melakukan kegiatan.

Masyarakat Jawa sragen yang masih menganut kepercayaan kejawen mempunyai kepercayaan terhadap hari baik dan hari buruk dalam melaksanakan aktivitas. Dalam 
perhitungannya masyarakat kejawen menggunakan rumus matematika yang sudah diwariskan oleh nenek moyang secara turun temurun. Namun tidak semua masyarakat mengerti tentang sistem perhitungan tersebut. Hanya orang-orang tertentu saja yang menguasai ilmu perhitungan tersebut. Diataranya orang yang mengerti adalah seorang sesepuh adat. Yang selalu menjadi panutan dalam melaksanakan berbagai upacara adat. Kepercayaan kejawen masih sangat dipengaruhi oleh agama Hindu dan Budha hal ini dapat dilihat dari perangkat-perangkat upacara adatnya.

Manfaat dari penelitian ini untuk Menginterpretasikan kebudayaan yang ada di masyarakat Sragen Jawa Tengah. Memudahkan peneliti dalam mempelajari kebudayaan dan norma-norma yang ada pada masyarakat Sragen, Jawa Tengah.Melestarikan Kebudayaan yang ada dalam Masyarakat yang semakin lama semakin hilang.Dapat memahami pola pikir masyarakat sragen yang menganut Kepercayaan Kejawen dan untuk media pengembangan ilmu.

\section{TINJAUAN PUSTAKA}

Menurut (D'Ambrosio : 2006) Istilah 'Ethnomathematics' yang selanjutnya dikenal dengan Etno-Matematika adalah "The prefix ethno is today accepted as a very broad term that refers to the socialcultural context and therefore includes language, jargon, and codes of behavior, myths, and symbols. The derivation of mathema is difficult, but tends to mean to explain, to know, to understand, and to do activities such as ciphering. measuring, classifying, inferring, and modeling. The suffix tics is derived from techné, and has the same root as technique.

Mengacu pada konteks sosial budaya, termasuk bahasa, jargon, kode perilaku, mitos, dan symbol. Kata dasar "mathema" cenderung berarti menjelaskan, mengetahui, memahami, dan melakukan kegiatan seperti pengkodean, mengukur, mengklasifikasi, menyimpulkan, dan pemodelan. Akhiran "tics "berasal dari techne, dan bermakna sama seperti teknik.

Ethnomathematika merupakan bidang penyelidikan yang mempelajari ide-ide matematika dalam konteks kebudayaan-sejarah mereka. Seorang peneliti mungkin tertarik untuk memahami peran dan perwujudan dari pemikiran matematika baik dalam penemuan dan menghasilkan pola-pola dekoratif. Jika tidak ada dialog langsung, secara fisik atau secara historis dengan penemu, memungkinkan kita (sebagai peneliti) untuk mencoba merekonstruksi unsur-unsur dari pemikiran matematika dengan terlibat dalam proses penemuan dan pembuatan.

Menurut Hadi Wijaya (2010:67) Ajaran kejawen, dalam perkembangan sejarahnya mengalami pasang surut. Hal itu tidak lepas dari adanya benturan-benturan dengan teologi dan budaya asing (Belanda, Arab, Cina, India, Jepang, AS). Yang paling keras adalah benturan dengan teologi asing, karena kehadiran kepercayaan baru disertai dengan upaya-upaya membangun kesan bahwa budaya Jawa itu hina, memalukan, rendah martabatnya, bahkan kepercayaan lokal disebut sebagai kekafiran, sehingga harus ditinggalkan sekalipun oleh tuannya sendiri, dan harus diganti dengan "kepercayaan baru" yang dianggap paling mulia segalanya. Dengan naifnya kepercayaan baru merekrut pengikut dengan jaminan kepastian masuk syurga. Gerakan tersebut sangat efektif karena dilakukan secara sistematis mendapat dukungan dari kekuatan politik asing yang tengah bertarung di negeri ini.

Sumardyono (2008 : 30) menyatakan ada empat obyek Matematika (1) Fakta, (2) Konsep (3) Operasi dan hubungan, dan (4) Prinsip. Benda keempat Matematika semua abstrak, karena hanya ada di pikiran manusia. Contoh fakta dalam Matematika, antara lain: "2" sebagai simbol nomor "dua"; "3 + 2" dipahami sebagai simbol "tiga ditambah dua"; dipahami sebagai simbol "bilangan irasional mendekati 3.14 "dan lain-lain. Konsep 
ini sangat terkait dengan definisi. Melalui definisi, seseorang dapat membedakan apa-apa termasuk konsep atau tidak konsep. Contoh konsep adalah: "segitiga", "bilangan prima", dan lain-lain. Operasi di Matematika terdiri dari operasi non biner dan biner operasi. Contoh operasi di Matematika, yaitu: "sum", akar kuadrat, dan lain-lain. Matematika adalah prinsip objek kompleks, yang terdiri dari beberapa fakta atau konsep dapat dinyatakan dengan hubungan atau operasi. Prinsip dapat "aksioma", "teorema" atau "proposisi," alam "atau" wajar", dan lain-lain

\section{METODE}

Metode yang digunakan dalam penelitian ini adalah metode survey Esploratif dengan pendekatan kualitatif etnografi. Dalam penelitian ini hanya mengkaji variabel tunggal yaitu etnomatematika. Sehingga penelitian ini tidak dimaksudkan untuk mencari hubungan antar variabel. Sampel penelitian ini adalah para sesepuh dan pemangku adat yang tinggal di wilayah Sragen Jawa Tengah yang peneliti anggap memahami tentang ajaran Kejawen. Buku tentang Ajaran kejawen. Dan Prosesi Upacara adat yang dilakukan Masyarakat Jawa Tengah.

Desain dan alur penelitian dalam penelitian ini adalah Desain yang peneliti gunakan adalah desain penentuan masalah Sugiyono (2009:31)

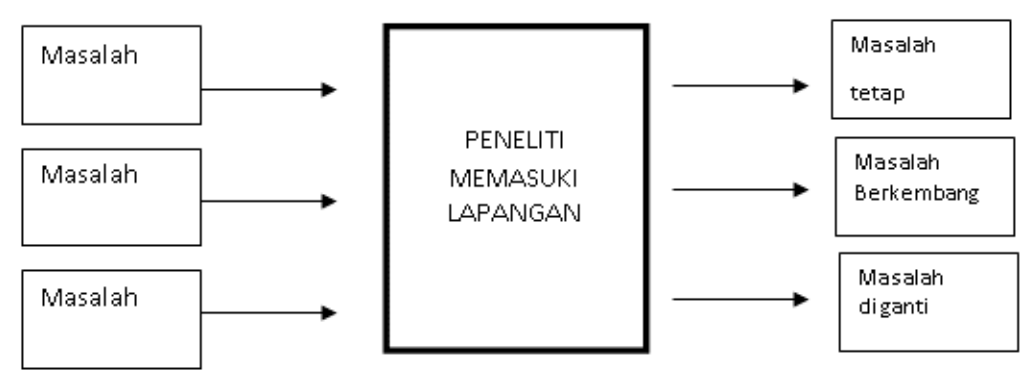

Gambar 1. Desain Penelitian

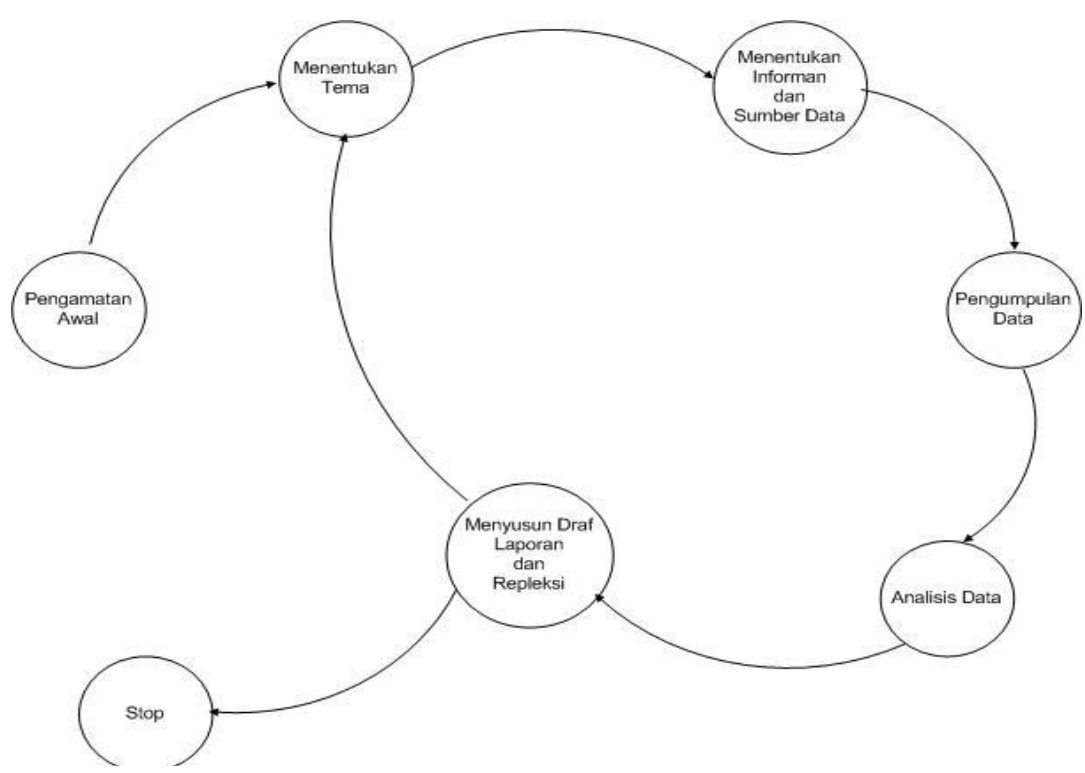

Gambar 2. Alur Penelitian 
Teknik pengumpulan data yang peneliti lakukan dalam penelitian ini adalah dengan teknik pengamatan dengan tiga metode yaitu Wawancara terhadap sesupuh adat, observasi dan studi dokumentasi.

\section{HASIL DAN PEMBAHASAN}

Analisis Unsur Fakta Matematika dalam Budaya Masyarakat Sragen Jawa Tengah

Dari temuan peneliti tentang fakta unsur waktu yang ada di budaya masyarakat Sragen Jawa Tengah seperti fakta unsur waktu hari tujuh, fakta unsur waktu hari pasaran, fakta unsur waktu bulan Jawa, dan fakta unsur waktu tahun windu. Fakta Unsur-unsur waktu yang ada dalam kebudayaan masyarakat Sragen merupakan bentuk transformasi dari hari tujuh, hari pasaran, bulan Jawa dan Tahun windu ke dalam simbol Matematika.

Unsur Waktu dalam kebudayaan Masyarakat Sragen Jawa Tengah perputaran atau rotasinya dapat dijelaskan dengan sistem jam Modulo, hari tujuh menggunakan sistem bilangan jam modulo 7 , hari pasaran menggunakan sistem bilangan jam modulo 5, bulan jawa menggunakan sistem bilangan jam modulo 12 dan tahun windu menggunakan sistem bilangan jam modulo 8 . Namun angka-angka yang ada dalam jam jam tidak sama dengan jam pada umumnya, karena peneliti menggunakan simbol bilangan Matematika yang merupakan fakta transformasi unsur waktu ke dalam simbol bilangan Matematika.

Tabel 1. Transformasi Hari tujuh kedalam Bilangan Matematika

\begin{tabular}{ccc}
\hline $\begin{array}{c}\text { Hari } \\
\text { ke }\end{array}$ & Sebutan & $\begin{array}{c}\text { Simbol bilangan } \\
\text { Matematika }\end{array}$ \\
\hline 1 & Minggu & 5 \\
2 & Senin & 4 \\
3 & Selasa & 3 \\
4 & Rabu & 7 \\
5 & Kamis & 8 \\
6 & Jumat & 6 \\
7 & Sabtu & 9 \\
\hline
\end{tabular}

Tabel 2. Transformasi Hari Pasaran kedalam Bilangan Matematika

\begin{tabular}{ccc}
\hline $\begin{array}{c}\text { Pasaran } \\
\text { ke }\end{array}$ & Sebutan & $\begin{array}{c}\text { Simbol bilangan } \\
\text { matematika }\end{array}$ \\
\hline 1 & Legi & 5 \\
2 & Pahing & 9 \\
3 & Pon & 7 \\
4 & Wage & 4 \\
5 & Kliwon & 8 \\
\hline
\end{tabular}


Tabel 3. Transformasi Bulan Jawa kedalam Bilangan Matematika

\begin{tabular}{clc}
\hline $\begin{array}{c}\text { Bln } \\
\text { ke }\end{array}$ & Sebutan & $\begin{array}{c}\text { Simbol bilangan } \\
\text { matematika }\end{array}$ \\
\hline 1 & Sura & 7 \\
2 & Sapar & 2 \\
3 & Mulud & 3 \\
4 & Bakda mulud & 5 \\
5 & Jumadilawal & 6 \\
6 & Jumadilakir & 1 \\
7 & Rejeb & 2 \\
8 & Ruwah & 4 \\
9 & Pasa & 5 \\
10 & Syawal & 7 \\
11 & Dulkangidah & 1 \\
12 & Besar & 3 \\
\hline
\end{tabular}

Tabel 4. Transformasi Tahun Windu kedalam Bilangan Matematika

\begin{tabular}{clc}
\hline $\begin{array}{c}\text { Tahun } \\
\text { ke }\end{array}$ & Sebutan & $\begin{array}{c}\text { Simbol bilangan } \\
\text { Matematika }\end{array}$ \\
\hline 1 & Alip & 1 \\
2 & Ehe & 5 \\
3 & Jimawal & 3 \\
4 & Je & 7 \\
5 & Dal & 4 \\
6 & Be & 2 \\
7 & Wawu & 6 \\
8 & Jimakir & 3 \\
\hline
\end{tabular}

\section{Analisis Unsur Operasi Matematika Dalam Budaya Masyarakat Sragen Jawa Tengah}

Operasi dalam Matematika adalah suatu aturan pengerjaan (hitung, aljabar, Matematia) operasi dapat berupa penjumlahan, pengurangan, perkalian dan pembagian, pemangkatan, dan pengakaran (Sadidah , 2014 :1). Dalam temuan penelitian ini unsurunsur Matematika dalam Kebudayaan masyarakat Sragen Jawa tengah terdapat prosedur atau operasi Matematika.

\section{Operasi Matematika dalam penentuan bilangan hari lahir}

Simbol bilangan seseorang sesuai dengan hari lahirnya yaitu penjumlahan hari tujuh dan hari pasaran. Dalam operasi Matematikanya hanya menggunakan operasi penjumlahan. Misalnya seseorang lahir pada hari minggu legi, minggu $=5$ dan legi $=5$, sehingga $5+5=10$, selengkapnya dapat dilihat dalam tabel 5 .

\section{Operasi Matematika dalam menentukan Perjodohan (salaki rabi)}

Berdasarkan studi pustaka buku Betaljemur (Tjakaraningrat : 1977 : 17) Dalam menentukan perjodohan bagi masyarakat sragen, Jawa tengah yang masih menganut kepercayaan kejawen, perhitungan dengan simbol bilangan Matematika Bulan lahir seseorang menggunakan operasi penjumlahan, pembagian dan aturan sisa bagi. 
Tabel 5. Jumlah Simbol Bilangan Hari Lahir

\begin{tabular}{|c|c|c|c|c|}
\hline \multicolumn{2}{|c|}{ Hari Tujuh } & \multicolumn{2}{|c|}{ Hari Pasaran } & \multirow{2}{*}{$\begin{array}{c}\text { Jumlah } \\
\text { Simbol } \\
\text { Bilangan }\end{array}$} \\
\hline Hari & $\begin{array}{c}\text { Simbol } \\
\text { Bilangan }\end{array}$ & Hari & $\begin{array}{c}\text { Simbol } \\
\text { Bilangan }\end{array}$ & \\
\hline \multirow[t]{5}{*}{ Minggu } & 5 & Legi & 5 & 10 \\
\hline & & Pahing & 9 & 14 \\
\hline & & Pon & 7 & 12 \\
\hline & & Wage & 4 & 9 \\
\hline & & Kliwon & 8 & 13 \\
\hline \multirow[t]{5}{*}{ Senin } & 4 & Legi & 5 & 9 \\
\hline & & Pahing & 9 & 13 \\
\hline & & Pon & 7 & 11 \\
\hline & & Wage & 4 & 8 \\
\hline & & Kliwon & 8 & 12 \\
\hline \multirow[t]{5}{*}{ Selasa } & 3 & Legi & 5 & 8 \\
\hline & & Pahing & 9 & 12 \\
\hline & & Pon & 7 & 10 \\
\hline & & Wage & 4 & 7 \\
\hline & & Kliwon & 8 & 11 \\
\hline \multirow[t]{5}{*}{ Rabu } & 7 & Legi & 5 & 12 \\
\hline & & Pahing & 9 & 16 \\
\hline & & Pon & 7 & 14 \\
\hline & & Wage & 4 & 11 \\
\hline & & Kliwon & 8 & 15 \\
\hline \multirow[t]{5}{*}{ Kamis } & 8 & Legi & 5 & 13 \\
\hline & & Pahing & 9 & 17 \\
\hline & & Pon & 7 & 15 \\
\hline & & Wage & 4 & 12 \\
\hline & & Kliwon & 8 & 16 \\
\hline \multirow[t]{5}{*}{ Jumat } & 6 & Legi & 5 & 11 \\
\hline & & Pahing & 9 & 15 \\
\hline & & Pon & 7 & 13 \\
\hline & & Wage & 4 & 10 \\
\hline & & Kliwon & 8 & 14 \\
\hline \multirow[t]{5}{*}{ Sabtu } & 9 & Legi & 5 & 14 \\
\hline & & Pahing & 9 & 18 \\
\hline & & Pon & 7 & 16 \\
\hline & & Wage & 4 & 13 \\
\hline & & Kliwon & 8 & 17 \\
\hline
\end{tabular}

Dalam penentuan perjodohan jumlahkan seluruh simbol bilangan Matematika bulan lahis kedua calon pasangan. Kemudian jumlah simbol bilangan Matematikanya dibagi dengan 10. Ketentuanya adalah sebagai berikut:

- Sisa bagi 0 disebut dengan rampas atau tidak boleh (tidak berjodoh)

- Sisa bagi 1 artinya wasesosegoro, kamot (menampung/luas), jembat budine (luas budi pekertinya), sugih pangapuro (pemaaf), gede prabawane (besar wibawanya). Artinya jika sisa satu itu baik.

- Sisa bagi 2 tungga semi, cepak rejekine (rejekinya tersedia), artinya sisa bagi 2 juga baik. 
- Sisa bagi 3 satria wibawa, mendapat kemuliaan dan keluhuran, sisa bagi 3 baik.

- Sisa bagi 4 sumursinaba jadi ahli ilmu, sisa bagi 4 baik.

- Sisa bagi 5 satriawirang, mendapat duka cipta, mendapat malu. Sisa bagi 5 tidak baik.

- Sisa bagi 6 bumikapethak, tabah dalam berumah tangga. Cukup baik.

- Sisa bagi 7 lebu ketiup angin, apa yang di harapkan tidak kesampaian. Sisa bagi 7 tidak baik.

- Sisa bagi 8 dan sisa bagi 9 tidak boleh dalam aturan sehingga pembaginya bukan 10 tetapi 7.

Sebagai contoh dalam perhitungan perjodohan, seorang laki-laki lahir pada kamis wage dan perempuan lahir pada bulan selasa kliwon.

- Jumlah simbol bilangan Matematika Laki-laki : $8+4=12$

- Jumlah simbol bilangan Matematika Perempuan $: 3+8=11$

- Jumlah simbol bilangan total $12+11=23$. Kemudia $23: 10=2$ sisa 3 .

Karena sisa tiga maka jatuhnya pada satria wibowo, artinya Jodohnya baik dalam berumah tangga nantinya akan mendapat kemuliaan dan keluhuran.

\section{Analisis Unsur Prinsip Matematika Dalam Budaya Masyarakat Sragen Jawa Tengah}

Dalam penelitian ini peneliti juga mengkaji tentanng prinsip dalam Matematika yang terkandung dalam Budaya Masyarakat Sragen Jawa Tengah. Prinsip dalam Matematika adalah sesuatu kajian yang dapat berupa theorema atau dalil (Sadidah, 2014: 1). Prinsip dalam matematika terdiri dari dua hal yaitu aksioma (Postulat) dan theorema.

Aksioma dalam matematika adalah sesuatu yang dianggap terbukti dengan sendirinya. Kata ini berasal dari $\alpha \xi$ loctv (axioein), yang berarti diangberharga, yang kemudian berasal dari $\alpha \xi 10 \varsigma$ (axios), yang berarti berharga. Aksioma adalah pendapat yang dijadikan pedoman dasar dan merupakan Dalil Pemula, sehingga kebenarannya tidak perlu dibuktikan lagi. Contoh dari aksioma adalah bahwa $5>3$, hal itu sudah pasti benar tanpa perlu ada yang membuktikanya lagi. Theorema adalah suatu pernyataan Matematika yang dirumuskan secara logika dan dibuktikan. Suatu theorema terdiri dari beberapa hipotesis dan kesimpulan, yang dapat dibuktikan dengan memanfaatkan istilah dasar, istilah terdefinisi, aksioma dan pernyataan benar lainya.

Dalam pembahasan mengenai prinsip ini kebenaran dari prinsip yang ada bukan suatu prinsip yang secara langsung dapat dibuktikan dengan pengukuran, namun harus dibuktikan dengan survey. Peneliti menganggap temuai berikut ini sebagai theorema karena definisi di atas. Prinsip yang dibahas adalah prinsip tentang watak atau karakter seseorang berdasarkan jumlah simbol bilangan Matematika berdasarkan transformasi hari lahir.

- Orang yang lahir dengan simbol bilangan 7 mempunyai watak pendiam, gampang tersinggung, pemarah, tidak punya kawan, tumpul pikiranya, sedikit punya watak suka bertindak kurang semestinya kepada perempuan (jika pria).

- Orang yang lahir dengan simbol bilangan 8 mempunyai watak pendengki, suka bertengkar, tidak mau kalah, banyak orang tersakiti hati karenanya bila ia seorang gadis, kadang-kadang suka mencelakakan seseorang yang menjadi teman aatau sanak saudara.

- Orang yang lahir dengan simbol bilangan 9 mempunyai watakpendiam, suka menyendiri, sering berpindah-pindah rumah, senang dipuja, jika gagal memperlihatkan kepandaianya kepada orang lain maka ia akan marah, hatinya selalu gelisah.

- Orang yang lahir dengan simbol bilangan 10 mempunyai watak pendiam tapi pikiranya tajam, gampang mempelajari aneka ilmu, bila marah suka dendam, 
kebanyakan jadi ilmu nujum, juga bakat jadi ilmu kebatinan, tutur katanya suka berlebihan, bisa jadi sastrawan.

- Orang yang lahir dengan simbol bilangan 11 mempunyai watak berani berjalan pada malam gelap gulita, tabah, dalam berpakaian tidak bisa awet sering dijual, suka terhadap harta orang lain, panjang tangan.

- Orang yang lahir dengan simbol bilangan 12 mempunyai watak kikir tetapi disukai dalam pergaulan baik teman wanita atau pria, dimanapun banyak kenalan, gampang mencari rejeki, dalam berumah tangga gampang bosan.

- Orang yang lahir dengan simbol bilangan 13 mempunyai watak pendiam, ramah tamah dan suka menolong, tetapi dijauhi teman, tidak pernah marah, suka begadang, pandai bicara, punya bakat dagang, kemauanya keras dan tidak mau dicegah, pendirianya kuat.

- Orang yang lahir dengan simbol bilangan 14 mempunyai watak setiap pekerjaan yang dikerjakan selesai dan rapih, cepat hidup bahagia dan tentram, cepat pandai, disukai banyak orang, berbudi luhur dan luas, bila malasnya datang sulit kaya.

- Orang yang lahir dengan simbol bilangan 15 mempunyai watak tutur katanya lemah lembut, menarik hati, pemaaf, selalu mengalah dalam perselisihan, pandai berkarya, bila makan tidak mau diganggu orang lain.

- Orang yang lahir dengan simbol bilangan 16 mempunyai watak jika merasa benar suka memerintah semaunya, kemamuanya keras, pandai silat lidah, tidak mau sampai kekurangan makan, tidak menghargai waktu.

- Orang yang lahir dengan simbol bilangan 17 mempunyai watak dalam ikhtiarnya suka menimbulkan bahaya, budi bahasanya merendah, dalam pembicaraan suka terputus, suka memandang rendah pada orang lain.

- Orang yang lahir dengan simbol bilangan 18 mempunyai watak pendengki, pencemburu, kalau mencela orang sering melampaui batas, perkataanya suka seenaknya, tidak mempertimbangkan perasaan orang lain.

\section{PENUTUP}

\section{Simpulan}

1. Kandungan unsur Fakta pada budaya Masyarakat Sragen Jawa Tengah terbagi kedalam dua kategori yaitu unsur waktu dan unsur non waktu. Unsur waktu yang ditransformasikan kedalam simbol Bilangan Matematika adalah hari tujuh, hari pasaran, bulan Jawa dan tahun windu. Transformasi hari tujuh kedalam simbol bilangan Matematika yaitu minggu : 5, senin, : 4, selasa : 3, rabu : 7, kamis : 8, Jumat : 6, Sabtu : 9. Transformasi hari pasaran dalam simbol bilangan Matematika yaitu, legi : 5, pahing : 9, pon : 7, wage : 4, kliwon : 8. Transformasi bulan Jawa kedalam simbol bilangan Matematika yaitu sura : 7, sapar ; 2, mulud : 3, bakda mulud : 5, jumadilawal : 6, jumadilakir : 1 , rejeb : 2 , ruwah $: 4$, pasa $: 5$, Syawal $: 7$, Dilkangidah : 1, besar : 3. Transformasi tahun windu kedalam simbol Bilangan Matematika yaitu alip : 1, Ehe : 5, jimawal : 3, Je : 7, dal :4, be : 2, wawu $: 6$, jimakir : 3. Dalam penelitian ini banyak sekali unsur-unsur Matematika yang dapat digali namun peneliti masih belum dapat menjawab "Bagaimana formulasi atau rumusan yang melandasi proses transformasi waktu dan non waktu ke dalam simbol bilangan Matematika yang digunakan Masyarakat Sragen Jawa Tengah ?. Selain unsur-unsur waktu ada juga unsur-unsur non waktu, seperti unsur arah mata angin, unsur warna, unsur logam, unsur air, unsur kayu, unsur burung, unsur pelindung dan unsur gejala alam. Namun bagaimana bentuk transformasi unsur-unsur non waktu ?, bagaimana unsur-unsur non waktu tersebut di implementasikan dalam budaya masyarakat Sragen Jawa Tengah? 
2. Kandungan unsur operasi Matematika yang diterapkan dalam unsur-unsur budaya masyarakat Sragen Jawa Tengah adalah bentuk operasi matematik yang umum digunakan oleh sebagian banyak orang. Seperti operasi penjumlahan, dalam menentukan jumlah simbol bilangan Matematika hari lahir seseorang maka operasi penjumlahan yang digunakan. Operasi pengurangan digunakan dalam penentuan rejeki dan perjodohan. Operasi pembagian digunakan dalam perjodohan. Serta sistem bilanagan jam dengan modulo 7 untuk hari tujuh, sistem bilangan jam modulo lima untuk hari pasaran, sistem bilangan jam modulo 12 untuk bulan jawa, dan sistem bilangan jam modulo 8 untuk tahun windu. Selain tiga operasi di atas apakah masih banyak lagi operasi yang lain?. Dalam perhitungan perjodohan rumusnya adalah jumlah simbol bilangan kedua calon di jumlah dan di bagi 10 sisa baginya yang digunakan sebagai patokan, namun bagaimana penetapan bagi 10?. Dan apa pula yang yang melandasi penentuan sisa bagi tersebut?

3. Kandungan Unsur prinsip Matematika yang diterapkan dalam unsur-unsur budaya masyarakat Sragen Jawa Tengah adalah bahwa simbol bilangan Matematika yang mewakili hari lahir seseorang dapat dicitak sebagai bentuk watak atau karakter yang dimiliki seseorang. Hasil penentuan karakter-karakter berdsarkan Primbon Jawa, menurut Narasumber Bapak Totok Yosmiran, S.S, keakuratan dari watak atau karakter yang dimiliki seseorang tersebut sampai 80\%. Primbon yang menggambarkan prinsip-prinsip Matematika dari jumlah simbol bilangan ini merupakan catatatan secara turun-temurun dari para peneliti di masa lampau. Namun pada kenyataanya mungkin masih banyak lagi. Selain prinsip yang peneliti temukan apakah masih banyak lagi prinsip matematika yang lain pada budaya masyarakat Sragen Jawa Tengah?

\section{Saran}

1. Bagi semua masyarakat Sragen Jawa Tengah, untuk senantiasa menjaga semua kebudayaan dan tatanan hidup yang berlaku di masyarakat.

2. Banyak yang salah dalam menafsirkan Primbon, primbon berarti Parimbuhan atau sebuah catatan yang disimpan. Hal-hal yang ada di primbon sesunggunya adalah catatan yang ditulis dari hasil pengamatan (penelitian) para filosof jaman dahulu.

3. Percaya terhadap sebuah pedoman hidup boleh, namun tetap pada hakekatnya kita tetap pada Agama dan kepercayaan terhadap Tuhan.

4. Saran untuk yang akan melaksanakan penelitian lanjutan dari penelitian ini adalah untuk lebih banyak lagi mencari data secara lebih mendalam.

5. Dalam penelitian ini masih banyak pertanyaan-pertanyaan atau masalah-masalah yang belum peneliti ungkapkan, sehingga penelitian ini perlu adanya penelitian lanjutan.

\section{DAFTAR PUSTAKA}

D'Ambrosio, U. 2006. Ethnomathematics: Link between traditions and modernity. ZDM, 40 (6), 1033-1034.

Sadidah. 2014. Unsur-unsur Matematika. Surakarta: UNS.

Sugiyono. 2009. Memahami Penelitian Kualitatif. Bandung: Alfabet.

Sumardyono. 2008. Karakteristik Matematika dan implikasinya terhadap pembelajaran Matematika. Yogyakarta: PPPG Matematika.

Tjakradiningrat. 1977. Kitab Primbon Betal Jemur Anammakna. Yogyakarta: Suemodijojo Mahadewa.

Wijaya, Hadi. 2010. Tokoh-tokoh Kejawen Ajaran dan Pengaruhnya. Yogyakarta: EULE. 